\title{
GUGATAN PEMBATALAN IZIN MENDIRIKAN BANGUNAN HOTEL SALAK TOWER
}

\author{
Geraldy Mista Putera \\ (Mahasiswa Program S1 Fakultas Hukum Universitas Tarumanagara) \\ (E-mail: geraldputera48@ gmail.com)
}

\section{Yuwono Prianto S.H., M.H.}

(Corresponding Author)

(Dosen Hukum Agraria Fakultas Hukum, Universitas Tarumanagara. Meraih Sarjana Hukum

(S.H) dari Universitas Tarumanagara (1987), Magister Hukum (M.H) dari Universitas

Tarumanagara (2005))

\begin{abstract}
Development is mostly carried out in aspects of human life to develop the economy and improve people's welfare. This construction is build upon permit in the form of a building permit issued by the government. The permit can also be canceled if it is deemed not in accordance with the applicable requirements. The goal of this investigation is to determine the resolution of the case and to find out whether the legal considerations given by the judge are correct or not. This investigation utilize normative legal research methods. The origin of legal material used in the research are primary legal library materials, secondary legal library materials, and tertiary legal library materials. This investigation used qualitative analysis. Based on an analysis of the sources of legal material that has been carried out, the authors conclude that the lawsuit against the cancellation of the building permit was registered past the deadline for the issuance date of the permit or has passed since the permit was announced at the time of the first construction, then the perceived loss the plaintiff is considered not a material loss and only concerned with the interests of one of the plaintiffs. As well as the legal considerations that have been conveyed, it is considered appropriate and when looking at the spatial plan of the Bogor Regency area, the location where the hotel is built is included in the area that allows for hotel buildings.
\end{abstract}

Keywords : Analysis of Decisions, Cancellation, Building permit.

\section{Pendahuluan}

\section{A. Latar Belakang}

Pada masa sekarang ini, banyak sekali pembangunan yang dilakukan dalam segala aspek kehidupan manusia. Pembangunan dilakukan secara merata dan menyeluruh. Kegiatan pembangunan yang dilakukan ini diharapkan dapat 
membangun perekonomian negara menjadi lebih baik dan dapat menyejahterakan masyarakat. Keterlibatan negara dan pemerintah menjadi faktor utama dalam menjalankan pembangunan ini karena negara dan pemerintah mengemban tanggung jawab dalam tujuan dari pembangunan ini.

Bangunan menjadi tempat dimana manusia melakukan berbagai macam aktivitas. Akan tetapi bangunan rumah bisa di kategorikan sebagai bangunan yang rentan terhadap kecelakaan apabila bangunan tersebut dibangun dengan tidak memperhatikan syarat - syarat yang ada. Bangunan didirikan dengan syarat pertimbangan yang telah diuji mengenai bentuk struktur dan kekuatan struktur serta kekuatan bahan yang digunakan. Dengan demikian bangunan tersebut akan memiliki umur yang panjang dan tidak mudah mencelakai orang di dalamnya, oleh karena itu peran pemerintah dinilai penting dengan melalui Izin Mendirikan Bangunan.

IMB itu sendiri adalah suatu izin yang bertujuan sebagai hal yang diberikan kepada pemohon dengan tujuan yaitu demi mengerjakan suatu kegiatan pembangunan apabila rencana yang telah disusun terhadap bangunan tersebut telah sesuai dengan aspek - aspek yang harus terpenuhi seperti aspek pertanahan, aspek perencanaan, aspek teknis, aspek kesehatan, aspek kenyamanan, dan aspek lingkungan. Menurut Teguh Wicaksono, Izin Mendirikan Bangunan atau disingkat IMB adalah izin untuk mendirikan, memperbaiki, menambah, mengubah, atau merenovasi suatu bangunan, termasuk izin kelayakan menggunakan bangunan atau untuk bangunan yang sudah berdiri yang dikeluarkan oleh Pemerintah Daerah. ${ }^{1)}$ IMB juga harus memenuhi aspek pertanahan, aspek perencanaan, aspek teknis, aspek kesehatan, aspek kenyamanan, dan aspek lingkungan. ${ }^{2)}$

\footnotetext{
1) Teguh Wicaksono, Konsep Pembangunan Perkotaan Indonesia, (Jakarta: LP3IS, 2005), hal. 2.

2) Jefrisen, "Studi Tentang Pelayanan Pemberian Izin Mendirikan Bangunan Di Kantor Pelayanan Perizinan Terpadu Pintu (KP2TSP) Kabupaten Kutai Barat", Jurnal Ilmu Pemerintahan, Volume 4, 2016, hal. 559.
} 
Persyaratan penerbitan dokumen IMB terdiri dari persyaratan administratif dan persyaratan teknis. ${ }^{3)}$ Tujuan dari penerbitan izin mendirikan bangunan dinyatakan oleh Philipus M. Hadjon, yaitu dapat berupa :

a. Keinginan mengarahkan (mengendalikan - "struren") aktivitas - aktivitas tertentu (misalnya izin bangunan).

b. Mencegah bahaya bagi lingkungan (izin - izin lingkungan).

c. Keinginan untuk melakukan perlindungan terhadap objek - objek tertentu (izin terbang, izin membongkar pada monumen - monumen).

d. Hendak membagi benda - benda yang sedikit (izin penghuni di daerah yang padat penduduk).

e. Pengarahan, dengan menyeleksi orang - orang dan aktivitas - aktivitas (izin berdasarkan "drank - en horecawet", di mana pengurus harus memenuhi syarat - syarat tertentu). ${ }^{4}$

Setiap dokumen IMB yang ingin di terbitkan, pemohon dari dokumen IMB tersebut akan dikenakan biaya berupa retribusi untuk biaya sempadan, biaya pengawasan, biaya konstruksi bangunan, dan biaya pendaftaran yang harus dibayar atau dilunasi oleh pemohon sebelum yang bersangkutan menerima surat IMB. ${ }^{5)}$

Pada saat melaksanakan pembangunan tersebut dibutuhkan perencanaan yang harus sesuai dengan peruntukan tanah tersebut. Rencana merupakan keseluruhan tindakan yang saling berkaitan dari tata usaha negara yang mengupayakan terlaksananya keadaan tertentu yang tertib. Dengan sendirinya, hanya rencana - rencana yang berkekuatan hukum yang memiliki arti bagi hukum administrasi negara. Suatu rencana dilakukan untuk menentukan kebijaksanaan apa yang akan dijalankan oleh tata usaha negara pada suatu lapangan tertentu. Rencana semacam itu atau seperti disebutkan di atas dapat dikaitkan dengan

\footnotetext{
3) Indonesia, Peraturan Menteri Pekerjaan Umum Nomor 05/PRT/M/2016 tentang Izin Mendirikan Bangunan Gedung (Berita Negara Republik Indonesia Tahun 2016 Nomor 276), Pasal 8.

4) Y.Sri Pudyatmoko, Perizinan, Problem dan Upaya Pembenahan, (Jakarta: PT Grasindo, 2009), hal. 11.

5) Faizal Madya, "Implementasi Kebijakan Izin Mendirikan Bangunan Di Kabupaten Bogor", Jurnal Organisasi dan Manajemen, Volume 4 nomor 2, September 2008, hal. 131.
} 
stelsel perijinan, misalnya suatu permohonan izin bangunan harus ditolak manakala hal tersebut bertentangan dengan rencana peruntukannya. ${ }^{6}$

Perencanaan ruang telah diatur dalam RTRW (Rencana Tata Ruang Wilayah) dengan menggunakan mekanisme pengendalian. Di dalam mekanisme pengendalian tersebut terdapat kegiatan pengawasan dan penertiban yang gunanya untuk menjaga agar tetap sesuai dengan RTRW. Perencanaan tata ruang diselenggarakan untuk menciptakan rencana umum tata ruang dan rencana rinci tata ruang. ${ }^{7)}$

\section{B. Perumusan Masalah}

Dalam penelitian ini rumusan masalah yang dibahas adalah bagaimana penyelesaian pada putusan peninjauan kembali Mahkamah Agung nomor 12 PK/TUN/2017 tentang gugatan pembatalan izin mendirikan bangunan hotel salak tower? Serta apakah dasar pertimbangan hakim pada putusan peninjauan kembali Mahkamah Agung nomor 12 PK/TUN/2017 tentang gugatan pembatalan izin mendirikan bangunan hotel salak tower sudah tepat?

Dengan melihat pada rumusan masalah yang telah disampaikan, maka hasil akhir yang diharapkan penulis dari penulisan ini yaitu melihat hasil penyelesaian pada putusan peninjauan kembali Mahkamah Agung nomor 12 PK/TUN/2017 tentang gugatan pembatalan izin mendirikan bangunan hotel salak tower, untuk mengetahui apakah hakim telah memberikan pertimbangan yang tepat terhadap gugatan pembatalan izin mendirikan bangunan hotel salak tower.

\section{Metode Penelitian}

6) Hasni, Hukum Penataan Ruang dan Penatagunaan Tanah dalam Konteks UUPA-UUPRUUPLH, (Jakarta: PT RajaGrafindo Persada, 2008), hal. 11.

7) Indonesia, Undang - Undang Nomor 26 Tahun 2007 tentang Penataan Ruang (Lembaran Negara Republik Indoneisa Tahun 2007 Nomor 68, Tambahan Lembaran Negara Republik Indonesia Nomor 4725), Pasal 14 ayat (1). 
Metode penelitian hukum yang dipakai penulis dalam penulisan ini yaitu metode penelitian hukum normatif. Dengan jenis data yang digunakan oleh penulis dalam melakukan penelitian adalah data sekunder yang dibagi kedalam bahan pustaka hukum primer, bahan pustaka hukum sekunder, dan bahan pustaka hukum tersier. ${ }^{8)}$

Bahan pustaka hukum primer yang digunakan dalam penulisan ini adalah Undang - Undang Nomor 26 Tahun 2007 tentang Penataan Ruang, Peraturan Pemerintah Nomor 36 Tahun 2005 tentang Peraturan Pelaksanaan Undang Undang Nomor 28 Tahun 2002 Tentang Bangunan Gedung, Peraturan Menteri Pekerjaan Umum Nomor 05/PRT/M/2016 tentang Izin Mendirikan Bangunan Gedung, Undang - Undang Nomor 1 Tahun 2011 tentang Perumahan dan Kawasan Permukiman, Peraturan Daerah Nomor 11 Tahun 2016 tentang Rencana Tara Ruang Wilayah Kabupaten Bogor 2016 - 2036.

Bahan pustaka hukum sekunder yang digunakan dalam penulisan ini adalah berbagai kepustakaan hukum yakni buku atau jurnal hukum yang berisi mengenai prinsip-prinsip dasar (asas hukum), pandangan para ahli hukum (doktrin) berupa semua penerbitan tentang hukum.

Bahan pustaka hukum tersier yang digunakan memiliki tujuan untuk memberi petunjuk serta penjelasan terhadap bahan hukum primer dan bahan hukum sekunder, yaitu adalah Kamus Hukum dan Kamus Besar Bahasa Indonesia.

Teknik pengumpulan data yang digunakan dalam penulisan ini adalah dengan studi pustaka terhadap bahan-bahan pustaka, baik bahan pustaka hukum primer, bahan pustaka hukum sekunder, dan bahan pustaka hukum tersier. ${ }^{9}{ }^{9}$ Teknik analisis data yang penulis gunakan dalam penelitian ini adalah teknik analisis kualitatif.

8) Soerjono Soekanto \& Sri Mamudji, Penelitian Hukum Normatif (Suatu Tinjauan Singkat). (Jakarta: Rajawali Pers, 2001), hal. 13.

9) Ibid., hal. 33. 


\section{Landasan Teori}

\section{A. Teori Negara Hukum}

Hukum sebagai acuan bagi manusia secara personal bukan sebagai suatu tujuan. Pada satu sisi, hukum itu diciptakan dengan tujuan melindungi tetapi di sisi lainnya sebagai pembatas. Hukum dibuat juga demi mengatur ketertiban, di sini hukum mejadi acuan sosial. Dengan pengertian hukum tersebut termasuk dalam acuan sosial, maka hukum tersebut lebih ditekankan sebagai perangkat negara maksudnya adalah usaha agar hukum dapat menjadi instrumen yang memiliki kekuatan legitimasi. ${ }^{10)}$

Ide dari negara hukum tersebut juga memiliki tujuan yaitu agar tidak terjadi suatu pemerintahan atau suatu negara dengan perbuatan yang sewenang - wenang. Sebab apabila suatu pemerintahan dijalankan tanpa adanya pengawasan yang dilakukan oleh hukum yang konkrit maka sangat memungkinkan terjadinya suatu penyalahgunaan kekuasaan secara sewenang wenang. ${ }^{11)}$

Menurut Satjipto Rahardjo, selama manusia hidup pada suatu negara ditemukan satu sistem hukum saja, tetapi terdapat banyak sistem hukum. Arti dari sistem hukum itu sendiri adalah sistem yang meliputi substansi, struktur, dan kultur hukum. Jika terdapat perbedaan pada unsur tersebut maka akan berakibat pada munculnya perbedaan dalam sistem hukum yang dipakai. ${ }^{12)}$

\section{B. Teori Kewenangan}

Seringkali kewenangan disamakan dengan kekuasaan tanpa melihat arti penting dari kedua hal tersebut. Kewenangan sesekali dikaitkan juga dengan

\footnotetext{
10) Fajlurrahman Jurdi, Teori Negara Hukum, (Malang: Setara Press, 2016), hal. 13 - 14.

11) Janpatar Simamora, "Tafsir Makna Negara Hukum Dalam Perspektif Undang - Undang Dasar Negara Republik Indonesia Tahun 1945”, Jurnal Dinamika Hukum, Volume 14 No. 3, September 2014, hal. 548.

12) Satjipto Rahardjo, Ilmu Hukum, (Bandung: PT. Citra Aditya Bakti, 2000), hal. 235.
} 
wewenang. Bentuk dari suatu kekuasaan biasanya ikatan dalam arti bahwa "ada satu pihak yang memerintah dan pihak lain yang diperintah" (the rule and the ruled). ${ }^{13)}$

Pengertian dari kata kekuasaan lebih lanjut juga disampaikan oleh Soerjono Soekanto yaitu sebagai suatu tindakan yang dikerjakan dengan tujuan untuk memberikan efek kepada orang lain oleh orang yang memegang kekuasaan. Adanya kekuasaan tersebut juga bergantung pada hubungan antara pemegang kekuasaan dengan yang dikuasai. ${ }^{14)}$

Pengertian mengenai wewenang didefinisikan sebagai suatu kepandaian untuk menjalankan suatu aktivitas yang diberikan oleh undang - undang untuk mengerjakan suatu relasi dan perbuatan hukum. ${ }^{15)}$ Pendeskripsian wewenang dari Philipus M. Hadjon menjelaskan bahwa wewenang setidaknya terdiri dari tiga komponen yaitu pengaruh, dasar hukum, dan konformitas hukum. ${ }^{16)}$

\section{Teori Perizinan}

Perizinan merupakan salah satu konstruksi tugas mengatur dari pemerintah. Perizinan adalah pemberian suatu izin (legalitas) kepada seseorang atau penyelenggara usaha/kegiatan tertentu. ${ }^{17)}$ Dengan memberi izin, pemilik dari kekuasaan memberikan suatu persetujuan untuk bertindak walaupun tindakan itu dilarang. Tindakan yang dilakukan memiliki relasi dengan kepentingnan umum dan perlu pengamatan khusu. Ini adalah definisi luas, dari izin itu sendiri. ${ }^{18)}$

\footnotetext{
13) Miriam Budiardjo, Dasar - Dasar Ilmu Politik, (Jakarta: PT Gramedia, 1981), hal. 35 - 36.

14) Lukman Hakim, "Kewenangan Organ Negara Dalam Penyelenggaraan Pemerintahan", Jurnal Konstitusi, Volume 4 No. 1, Juni 2011, hal. 115 - 116.

15) S.F. Marbun, Peradilan Administrasi Negara dan Upaya Administrasi di Indonesia, (Yogyakarta: Liberty, 1997), hal. 154.

16) Philipus M. Hadjon dalam Sukardi, "Wewenang Pembatalan Peraturan Daerah", Jurnal Law Review, Volume XII No. 3, Tahun 2013, hal. 410.

17) Evy Urmilasari et al., "Analisis Pelayanan Perizinan di Badan Perizinan Terpadu dan Penanaman Modal Kota Makassar", Jurnal Ilmu Pemerintahan, Volume 6, Januari 2013, hal. 50.

${ }^{18)}$ N.M. Spelt dan J.B.J.M. ten Berge, Pengantar Hukum Perizinan, disunting oleh Philipus M. Hadjon, (Surabaya : Yuridika, 1993), hal. 2-3.
} 
Perizinan juga dipakai oleh pemerintah sebagai wadah atau sarana menjalankan pengawasan terhadap aktivitas karena perizinan adalah sebagai alat untuk terlindung dari hukum atas tindakan yang dilakukan. Pelayanan perizinan itu sendiri dilakukan oleh pemerintah untuk memberikan hak secara sah atas suatu kepemelikan dari individu atau organisasi. ${ }^{19)}$

\section{Pembahasan}

Penelitian terhadap putusan PK dengan nomor 12 PK/TUN/2017 dengan pihak yang berperkara adalah Prof. Dr. Ir. Ahmad Bey, Budi Suryono, Lie Argon Bastari, Tumpak Rendra Siahaan, dan Japananto sebagai para pemohon peninjauan kembali. Serta Walikota Bogor dan PT Hotel Properti Internasional sebagai para termohon peninjauan kembali. Objek gugatan yang dipermasalahkan dalam gugatan tersebut adalah Surat Keputusan Walikota Bogor Nomor 644-530BPPTPM-IV/2013 tentang Izin Mendirikan Bangunan atas nama PT Hotel Properti Internasional yang dikeluarkan pada tanggal 22 April 2013.

Para penggugat mengemukakan gugatan dengan berdasarkan kepada SEMA Nomor 2 Tahun 1991 pada angka romawi V angka 3 juncto Pasal 55 Undang - Undang Nomor 5 Tahun 1986 tentang Peradilan Tata Usaha Negara yang menyebutkan bahwa bagi mereka yang tidak dituju oleh suatu Keputusan Tata Usaha Negara tetapi yang merasa kepentingannya dirugikan maka tenggang waktu sebagaimana dimaksud Pasal 55 dihitung saat ia merasa kepentingannya dirugikan oleh Keputusan Tata Usaha Negara dan mengetahui adanya keputusan tersebut.

Gugatan yang dikemukakan oleh para pemohon tersebut juga mempunyai dasar sebagaimana yang telah dikemukakan bahwa Informasi mengenai Surat Keputusan tersebut menurut para penggugat baru diketahui dan diperoleh salinan atas Surat Keputusan Walikota Bogor Nomor 644-530-BPPTPM-IV/2013 tentang Izin Mendirikan Bangunan atas nama PT Hotel Properti Internasional tertanggal

19) Mohammad Haidar Mustaghfiri, Priyanto Susiloadi, "Kualitas Pelayanan Penerbitan Izin Mendirikan Bangunan di Dinas Penanaman Modal dan Pelayanan Terpadu Satu Pintu Kota Surakarta", Jurnal Wacana Publik, Volume 1 No. 2, 2017, hal. 25. 
22 April 2013 pada tanggal 25 Mei 2015 yang diketahui dari Ketua Rukun Tetangga (RT).

Pernyataan yang telah disampaikan oleh para penggugat bahwa mereka adalah tetangga dan masyarakat yang telah tinggal lama di kawasan tersebut, mereka memliki suatu kepentingan yang dirugikan dengan adanya kegiatan pembangunan tersebut. Sebab dengan adanya pembangunan tersebut kepentingan yang dirugikan dari para penggugat yaitu berupa hilangnya privasi serta kerugian seperti terhalangnya cahaya matahari dan sebagainya.

Selanjutnya, dengan adanya uraian yang menyebutkan bahwa para penggugat adalah tetangga dari gedung yang sedang dibangun, maka para penggugat memiliki suatu kepentingan terhadap pembangunan gedung tersebut sehingga perkara a quo yang diajukan oleh penggugat telah memenuhi adanya unsur "Kepentingan" dalam mengajukan gugatan di pengadilan Tata Usaha Negara.

Selain dari itu para penggugat juga menyampaikan pembangunan gedung tersebut dilakukan tanpa dilengkapi amdal sehingga berakibat melanggar hak partisipasi dari para penggugat pada aktivitas bagi lingkungan hidup serta melanggar hak dari para penggugat untuk memperoleh lingkungan yang baik dan sehat.

Penggugat juga menyatakan bahwa surat pernyataan tidak keberatan dari tetangga yang telah disebutkan sangat dirasa tidak adil bagi para penggugat karena hanya ditandatangani oleh 3 orang yang semuanya tidak bertempat tinggal di sekitar bangunan gedung tersebut, sehingga 3 orang tersebut tidak memenuhi syarat sebagai tetangga dan dalam surat tersebut tidak disebutkan peruntukannya.

Terhadap hal - hal yang telah diuraikan diatas tergugat juga memberikan tanggapan yaitu bahwa gugatan yang diajukan telah lewat waktu karena Surat Keputusan Walikota Bogor Nomor 644-530-BPPTPM-IV/2013 tentang Izin Mendirikan Bangunan atas nama PT Hotel Properti Internasional telah diterbitkan 
pada tanggal 22 April 2013 kemudian juga telah dipasang pemberitahuan sebelum dilakukannya pembangunan pada tanggal 13 Desember 2013.

Selanjutnya segala alasan yang dicantumkan terkait kepentingan yang dirugikan sebagai dasar gugatan oleh para penggugat dinilai tidak memiliki Legal Standing karena tidak dapat dibuktikan dan tidak diuraikan dengan jelas oleh penggugat serta tidak seluruh dari penggugat berbatasan atau bertetanggaan langsung dengan bangunan gedung hotel tersebut melainkan hanya 1 orang saja.

Dengan mengacu pada hal tersebut seharusnya para penggugat telah mengetahui akan adanya surat izin mendirikan bangunan tersebut dan jika ada kepentingan yang dirugikan apabila berhubungan dengan para penggugat, maka seharusnya gugatan yang dikemukakan oleh para penggugat memiliki batas akhir pada tanggal 21 Juli 2013 terhitung sejak objek gugatan diterbitkan atau paling tidak berakhir pada tanggal 12 Maret 2014 sejak pengumuman objek gugatan yang dipasang sebelum pembangunan pada tanggal 13 Desember 2013.

Sehingga seharusnya gugatan diajukan paling lambat pada tanggal 21 Juli 2013 terhitung sejak objek gugatan diterbitkan atau paling lambat pada tanggal 12 Maret 2014 sejak pengumuman objek gugatan yang dipasang sebelum pembangunan pada tanggal 13 Desember 2013. Maka terhadap dasar pengajuan gugatan ini dinilai para penggugat telah melewati tenggang waktu untuk mendaftarkan atau mengajukan gugatan kepada peradilan tata usaha negara bandung.

Sementara itu penyelesaian terhadap alasan diajukannya gugatan yang mana para penggugat menyatakan bahwa ada kepentingan dari para penggugat yang merasa dirugikan dan dirasakan oleh para penggugat yang menjadi dasar tersebut dinilai tidak tepat karena penggugat tidak menguraikan serta tidak membuktikan tentang kepentingan yang dirasa dirugikan oleh tergugat. Kemudian juga tidak seluruh dari para penggugat merupakan warga yang berkedudukan atau bertempat tinggal di sekitar lokasi pembangunan tetapi hanya 1 orang penggugat saja yang tinggal bersebelahan. 
Serta terhadap alasan mengenai ketidaksesuaian pembangunan gedung hotel dengan Rencana Tata Ruang Wilayah Kota Bogor, pada gambar Rencana Tata Ruang Wilayah Kota Bogor bangunan tersebut terletak di tepian kawasan pusat kota dan sub pusat kota serta kawasan strategis budaya dan kawasan strategis ekonomi dan juga terletak pada kawasan perdagangan bogor lama.

Maka dari itu terhadap alasan - alasan yang diajukan oleh penggugat sebagai dasar adanya gugatan tersebut dinilai tidak tepat karena kepentingan yang dirugikan hanya berkaitan dengan salah satu penggugat dan tidak dirasakan oleh penggugat lainnya karena tidak bersebelahan secara langsung, serta pada rencana tata ruang wilayah kota bogor telah disebutkan wilayah tempat berdirinya bangunan gedung hotel tersebut sehingga sangat dimungkinkan terdapat bangunan hotel pada kawasan tersebut.

Kemudian, pada putusan PK dengan nomor 12 PK/TUN/2017 dengan pihak yang berperkara adalah Prof. Dr. Ir. Ahmad Bey, Budi Suryono, Lie Argon Bastari, Tumpak Rendra Siahaan, dan Japananto sebagai para pemohon peninjauan kembali. Serta Walikota Bogor dan PT Hotel Properti Internasional sebagai para termohon peninjauan kembali terdapat pertimbangan hukum yang disampaikan untuk menyelesaikan kasus tersebut.

Bahwa putusan pengadilan tinggi Jakarta telah berkekuatan hukum tetap, sudah tepat dan benar, karena izin mendirikan bangunan yang digugat diterbitkan tanggal 22 april 2013 dan pembangunan fisik gedung yang dilakukan memiliki pemberitahuan terhadap izin tersebut telah di pasang papan pengumuman di tempat pembangunan dan dapat dilihat pada tahun 2013, sedangkan gugatan yang dikemukakan oleh para penggugat didaftarkan pada tanggal 29 juli 2015 sehingga gugatan tersebut telah lewat waktu sembilan puluh hari.

Menimbang berdasarkan pertimbangan yang telah disampaikan maka permohonan peninjauan kembali dari para pemohon tidak beralasan sehingga harus ditolak, serta dengan ditolaknya permohonan tersebut maka pemohon 
dinyatakan sebagai pihak yang kalah dan dihukum untuk membayar biaya perkara dalam perkara tersebut.

Apabila melihat kepada pertimbangan hukum yang telah diberikan pada putusan tersebut, maka peneliti menanggapi terhadap pertimbangan tersebut bahwa penggugat dinyatakan ditolak permohonannya dikarenakan pendaftaran telah melewati batas waktu dinilai dapat menjadi faktor yang penting, sebab terbitnya izin mendirikan bangunan tersebut dan pelaksanaan pembangunan sebagaimana telah diberikan papan pengumuman pada lokasi bangunan sudah melewati dari tanggal pendaftaran gugatan.

Kemudian selain dari pertimbangan dan tanggapan yang telah peneliti sampaikan, peneliti juga menanggapi bahwa para penggugat yang mendaftarkan gugatan tersebut berdasarkan alasan - alasan yang telah disampaikan oleh peneliti dinilai berlebihan, sebab apabila dilihat pada peraturan yang telah diterbitkan bahwa pada kawasan tempat bangunan hotel itu berada di tepian kawasan pusat kota dan sub pusat kota serta kawasan strategis budaya dan kawasan strategis ekonomi dan juga terletak pada kawasan perdagangan bogor lama, sehingga sangat memungkinkan didirikannya hotel pada kawasan tersebut.

\section{Penutup}

\section{A. Kesimpulan}

Berdasarkan data yang telah disampaikan oleh penulis, mengenai penyelesaian dari Putusan PK No. 12/PK/TUN/2017 Tentang Gugatan Pembatalan Izin Mendirikan Bangunan Hotel Salak Tower, kesimpulannya adalah bahwa gugatan yang telah didaftarkan oleh penggugat dinilai tidak sesuai dan tidak memiliki legal standing serta perihal alasan - alasan yang dicantumkan oleh penggugat mengenai kerugian yang dialami selama proses pembangunan hotel tersebut dinilai bukan merupakan kerugian secara materil dan hanya berfokus pada salah satu penggugat, sehingga gugatan tersebut dinilai tidak dapat diterima. 
Mengenai pertimbangan hukum yang diberikan oleh hakim dalam Putusan PK No. 12/PK/TUN/2017 Tentang Gugatan Pembatalan Izin Mendirikan Bangunan Hotel Salak Tower apabila dilihat dari data yang telah penulis sampaikan, pertimbangan hukum tersebut dinilai tepat diberikan karena penggugat mendaftarkan gugatan melebihi dari tanggal terakhir sejak diterbitkannya surat keputusan walikota Bogor nomor 644-530-BPPTPM-IV/2013 tentang izin mendirikan bangunan atas nama PT Hotel Properti Internasional yang dikeluarkan pada tanggal 22 April 2013 dengan tanggal terakhir pendaftaran gugatan yaitu tanggal 21 Juli 2013 atau pada saat objek gugatan tersebut diumumkan pada tanggal 13 Desember 2013 dengan tanggal terakhir 12 Maret 2014. Sedangkan gugatan diajukan pada tanggal 29 Juli 2015, berdasarkan pertimbangan hukum dari putusan tersebut maka dinilai sudah tepat bahwa gugatan didaftarkan telah lewat jangka waktu.

\section{B. Saran}

Berdasarkan kesimpulan yang telah disampaikan oleh penulis, maka penulis memberikan saran terhadap penelitian yang dilakukan oleh penulis yaitu sebagai berikut:

1. Bagi masyarakat, hasil dari penelitian yang telah dilakukan oleh penulis diharapkan dapat menjadi suatu pembelajaran sehingga apabila masyarakat berhadapan dengan kasus serupa masyarakat harus mengetahui secara rinci mengenai penerbitan surat izin mendirikan bangunan yang sekiranya akan digugat untuk diajukan pembatalan.

2. Bagi pemegang surat izin mendirikan bangunan, berdasarkan hasil penelitian yang telah dilakukan, diharapkan dapat menjadi suatu acuan bagi para pemegang surat izin mendirikan bangunan tersebut untuk melakukan penyampaian secara menyeluruh kepada semua masyarakat yang berada pada sekitar lokasi tempat bangunan akan dibangun serta memberikan penjelasan serta ganti rugi secara jelas apabila pada saat penyampaian tersebut ada masyarakat yang merasa dirugikan. 


\section{DAFTAR PUSTAKA}

\section{A. Buku}

Budiardjo, Miriam. Dasar - Dasar Ilmu Politik, (Jakarta: PT Gramedia, 1981).

Hasni. Hukum Penataan Ruang dan Penatagunaan Tanah dalam Konteks UUPA-UUPR-UUPLH, (Jakarta: PT RajaGrafindo Persada, 2008).

Jurdi, Fajlurrahman. Teori Negara Hukum, (Malang: Setara Press, 2016).

Marbun, S.F. Peradilan Administrasi Negara dan Upaya Administrasi di Indonesia, (Yogyakarta: Liberty, 1997).

Pudyatmoko, Y.Sri. Perizinan, Problem dan Upaya Pembenahan, (Jakarta: PT Grasindo, 2009).

Rahardjo, Satjipto. Ilmu Hukum, (Bandung: PT. Citra Aditya Bakti, 2000).

Soekanto, Soerjono \& Sri Mamudji. Penelitian Hukum Normatif (Suatu Tinjauan Singkat). (Jakarta: Rajawali Pers, 2001).

Spelt, N.M. dan J.B.J.M. ten Berge. Pengantar Hukum Perizinan, disunting oleh Philipus M. Hadjon, (Surabaya : Yuridika, 1993).

Wicaksono, Teguh. Konsep Pembangunan Perkotaan Indonesia, (Jakarta: LP3IS, 2005).

\section{B. Artikel Jurnal}

Hadjon, Philipus M. dalam Sukardi. "Wewenang Pembatalan Peraturan Daerah", Jurnal Law Review, Volume XII No. 3, Tahun 2013.

Hakim, Lukman. "Kewenangan Organ Negara Dalam Penyelenggaraan Pemerintahan", Jurnal Konstitusi, Volume 4 No. 1, Juni 2011.

Jefrisen, "Studi Tentang Pelayanan Pemberian Izin Mendirikan Bangunan Di Kantor Pelayanan Perizinan Terpadu Pintu (KP2TSP) Kabupaten Kutai Barat”, Jurnal Ilmu Pemerintahan, Volume 4, 2016.

Madya, Faizal. "Implementasi Kebijakan Izin Mendirikan Bangunan Di Kabupaten Bogor", Jurnal Organisasi dan Manajemen, Volume 4 nomor 2, September 2008.

Mustaghfiri, Mohammad Haidar, Priyanto Susiloadi, "Kualitas Pelayanan Penerbitan Izin Mendirikan Bangunan di Dinas Penanaman Modal dan 
Pelayanan Terpadu Satu Pintu Kota Surakarta", Jurnal Wacana Publik, Volume 1 No. 2, 2017.

Simamora, Janpatar. "Tafsir Makna Negara Hukum Dalam Perspektif Undang Undang Dasar Negara Republik Indonesia Tahun 1945", Jurnal Dinamika Hukum, Volume 14 No. 3, September 2014.

Urmilasari, Evy, et al. "Analisis Pelayanan Perizinan di Badan Perizinan Terpadu dan Penanaman Modal Kota Makassar", Jurnal Ilmu Pemerintahan, Volume 6, Januari 2013.

\section{Perundang - Undangan}

Indonesia, Peraturan Menteri Pekerjaan Umum Nomor 05/PRT/M/2016 tentang Izin Mendirikan Bangunan Gedung (Berita Negara Republik Indonesia Tahun 2016 Nomor 276).

Undang - Undang Nomor 26 Tahun 2007 tentang Penataan Ruang (Lembaran Negara Republik Indoneisa Tahun 2007 Nomor 68, Tambahan Lembaran Negara Republik Indonesia Nomor 4725). 